\title{
Interest and Creativity as Determinative Factors on Students' Achievement
}

\author{
(A Study to Students of Economy Subject at SMAN 1 Sambas)
}

\author{
Junaidi H. Matsum \\ Department of Economy Education \\ Tanjungpura University \\ Pontianak, Indonesia \\ prof.junaidimatsum@gmail.com
}

\begin{abstract}
The general problem in this study is: "How interest and creativity are as determinative factors on students' achievement on the Economy subject at SMAN 1 Sambas. Subpoints of the problems are as follows: (1) whether interest is a factor affecting students' achievement on the Economy subject at Senior High School 1 Sambas; (2) whether creativity is a factor affecting students' achievement on the Economy subject at SMAN 1 Sambas; and (3) whether interest and creativity join together as the factors affecting students' achievement on the Economy subject at SMAN 1 Sambas. This study employed descriptive method with a correlational study. The independent variables of this study are students' interest and creativity. Meanwhile, the dependent variable is students' achievement on the Economy subject. The population of this study is students' who officially enrolled on the Economy subject at SMAN 1 Sambas. The sample was taken from all students in the eleventh grade based on their characteristics. Sampling was done by using cluster purposive random sampling technique. The total number of sample was 40 students. Regarding the technique of this study, it used indirect communication and documentary technique. This study concluded that: (1) interest Factor gives a significant effect on students' achievement in economic subject at SMAN 1 Sambas. (2) creativity Factor gives a significant effect on students' achievement on the Economy subject at SMAN 1 Sambas. (3) interest and creativity Factors that are joined together gives a significant effect on students' achievement on the Economy subject at SMAN 1 Sambas.
\end{abstract}

\section{Keywords-Interest, Creativity, Economy Subject}

\section{INTRODUCTION}

A number of studies have been conducted to identify and analyze numerous factors affecting the success of students' achievement. It revealed that in fact, academic performance is significantly influenced by sort of factors: interest in learning [1], parents' education, family income [2], self-motivation, the age of student, learning preferences [3], class attendance [4]. Among those factors, students' interest could most probably be a pivotal factor in learning. Therefore, it is important to bear in mind that students' interest gives a powerful effect on students' learning experience. According to [5] "Interest is having a strong desire or eagerness toward something". In other words, interest is a high desire that leads one to do something. By referring to this, it can be inferred that students who devote their interest on the Economy subject will eventually feel happy and strongly captivate in learning which can be measured by their participation in the classroom.

However, there have been facts that the teaching and learning process is entirely dominated by teachers. Obviously, there were approximately $70 \%$ of school hours is merely controlled by teaching without giving any chance for students to be actively involved in the activity. As a result, the students feel less keen and relatively have low interest in learning. Moreover, their creativity is not fully concerned by the teacher.

Based on the aforementioned evidence, the writer is interested in conducting a research concerning how interest and creativity be determinative factors on students' achievement on the Economy subject at SMAN 1 Sambas. The utility of this study lies in the need to improve the ability for teachers in teaching and learning process so that it can give students much more opportunity to increase their interest and creativity which in turn contribute to the improvement of students' achievement.

The teaching process indeed demands students' interest in learning. Interest is defined by [6] as the attention with a sense of concern; lively sympathy or curiosity; and the power to excite or hold such attention (in something). Reference [7] pointed out that interest is a tendency of such subject to be interested in something and excited to get involved in it. Interest may substantially influence educational and occupational achievement, interpersonal relations, and major phases of daily living [1]. In the meantime, [8] asserted that interest is a propulsion that promotes students' ability with a sense of concern toward everything that probably influences experience. "Interest plays an important role in the field of psychology as a number of researchers have shown that it is related to personality, motivation, cognition, development, emotion, vocations, aesthetics, behavior, hobbies, reasoning, and information processing [9].

In this study, interest is regarded as a positive attitude that motivates individual to have a propulsion, or being energized in learning economy subject, which will be measured by (a) Listening to teacher's explanation. (b) Have a high curiosity in which students will ask questions regarding something they do not understand. (c) Answer teacher's questions. (d) Keep on reading on the economy book without teachers' command. (e) Regularly make a note-taking on the Economy subject. (f) 
Mastering subjects they like than other subjects. (g) Be able to retell or re-explain to others about the Economy subject.

Creativity is a complex capacity of human intelligence to bring something new, which is relevant to everyone and covers both individual and collaborative activities [10]. Reference [11] sounded the same, asserting that creativity as the act of turning new and imaginative ideas into reality which involves two processes: thinking, then producing. According to [12], creativity is typically defined as the generation or production of ideas or solutions that are both novel and useful.

In addition to this, [13] stated that creativity is a process that manifests itself to be an independent thinker, imaginative, energetic, and able to take the risk. Reference [14] defined creativity as the forming of associative elements into a new combination which either meet specified requirements or are in same ways useful. The more mutually remote the elements of the new combination, the more creative the process solution.

By highlighting the aforementioned definitions, it can be inferred that creativity in this study is a process in which the students have the ability to use imaginative ideas involving thinking and producing to create something new. In practice, it will be measured by: (a) having high curiosity (b) opening to new experience, (c) being initiative, (d) thinking independently, (e) having self-confident, (f) having willingness to take the risk, (g) eager to find and analyze something, (h) tend to like challenging tasks, (i) finding out the answers properly, (j) responding questions and answer more.

Academic achievement of students is one of the major determinants of the future of a young generation. In the mean time, what is meant by learning achievement is the outcomes of learning [15]. While [16] stated that achievement is something done successfully, with effort and skill. A similar idea is asserted by [17], stating that achievement is the expectancy of finding satisfaction in mastering challenging and difficult performances which usually comes from specific instruction.

Thus, achievement in this study is learning outcomes gained by students in the eleventh grade at SMAN 1 Sambas which is reflected from their daily test in the even semester of academic year 2015/2016.

\section{METHODS}

This research employed descriptive method with a correlational study. The target population for this study comprised all students in Social Education at SMAN 1 Sambas. Regarding the sample, the writer used Cluster Purposive Random sampling technique [18]. There were 40 students who officially enrolled in eleventh grade was taken as sample based on their characteristics. Meanwhile, indirect communication through questionnaire was used as the technique for collecting the data. Moreover, documentary study with note taking is also used to gain the empirical data.

\section{RESUlTS AND DISCUSSION}

\section{A. Research Results}

The contribution of interest on the learning outcomes is indicated by the coefficient of determination of $11.4 \%$. Thus, the students' interest has $11.4 \%$ of influence on their learning results of the economy subject in the eleventh grade at SMAN 1 Sambas and while the remaining $88.6 \%$ is influenced by other factors outside of this study. Hypothesis test results showed that the students' interest factor significantly influenced students' learning outcomes of the economy subject in XI grade at SMAN 1 Sambas.

The contribution of creativity on the learning outcomes is indicated by the coefficient of determination of $12.9 \%$. Thus, the students' creativity has $12.9 \%$ of influence on their learning results of economy subject in XI grade at SMAN 1 Sambas and while the remaining $87,1 \%$ is influenced by other factors outside of this study. Hypothesis test results showed that the students' creativity factor significantly influenced students' learning outcomes of economy subject in XI grade at SMAN 1 Sambas.

The contribution of interest and creativity on the learning outcomes is indicated by the value of $\mathrm{R}$ square which is 0.170 , meanwhile, the coefficient determination is $0.170 \times 100 \%$. Thus, the coefficient of determination is $17 \%$. Hence, the students' interest and creativity together have $17 \%$ of influence on their learning results of the Economy subject in XI grade at SMAN 1 Sambas and while the remaining $83 \%$ is influenced by other factors outside of this study. Hypothesis test results revealed that the students' interest and creativity significantly influenced students' learning outcomes of the Economy subject in XI grade at SMAN 1 Sambas.

\section{B. Discussion}

1) The Students' Interest Factor Influenced the Students' Learning Outcomes of Economy Subject

This condition shows that interest has an important role in the learning process. In accordance with the opinion by [7] who argued: "interest in learning is a tendency of a subject to be persistent, to feel attracted to a particular field of study, and to be pleased to learn a material". Furthermore, according to [19] "interest in learning is a pleasure in doing the activities, and is able to excite a person to fulfill the willingness that can be measured through the difficulties, interest, concern, and involvement". Thus, students, who have a higher interest in learning, have a sense of fun, while learning economy and have the drive to succeed and avoid failure. Similarly, students who have interest in learning will have interest and attention in learning economy. Instead, students who have lower learning interest have no pleasure in studying economy and do not have the drive to achieve higher learning outcomes. Students learning cannot be delegated to others. Interest is an internal factor in students to achieve success in learning. Students who have lower interest in learning are difficult to expect a commitment and tenacity in learning. There is a relationship between interest and learning outcomes. The existence of the high interest on the Economy subject will affect the learning outcomes. In other words, the students' interest affects the 
learning outcomes. Thus, the conclusion of this study supports the preceding theories. Interest factor significantly influences the improvement of learning outcomes. Students with high interest will obtain high learning outcomes are high and vice versa low interest students will obtain low learning outcomes. In addition to the interest factor, of course, there are many other factors that affect the student learning outcomes.

2) The Students' Creativity Factor Influenced the Students' Learning Outcomes of Economy Subject

The second hypothesis testing obtained tobtain value of 5.732. tobtain value $(5.732)>$ ttable $(1.701)$ is accepted at a significance level of $5 \%$, then $\mathrm{Ho}$ is rejected and $\mathrm{Ha}$ is accepted, which means creativity significantly affects the students' learning outcomes of economy subject in X1 class at SMAN 1 Sambas. This shows that creativity has an important role in the learning process. Students who have high creativity obtain high learning outcomes; otherwise, the students who have low creativity obtain lower learning results. The hypothesis acceptance is supported by the opinion of [20] who argued as follows:

Creativity in learning is the ability to connect and link (sometimes with bizarre yet impressive manner) which is the basis of creative thinking utilization of human spiritual potency in all fields. When students have high creativity, then the resulting behavior is a positive activity in the form of creativity in developing a new understanding, so gain an optimal performance.

Thus, the students' creativity determines the level of learning outcomes to be achieved. The creative students have characteristics: a strong curiosity, trying to put forward ideas, passionate, active, dedication to duty and took the initiative to work. These conditions make students succeed in learning and ultimately improve their learning outcomes. Reference [13] described one of the factors for determining one's giftedness is creativity to excel. Creativity or inventiveness enables new discoveries in the field of science and technology and in all areas of business and others. Creativity involves learning to solve problems and requires critical thinking, the reality of spontaneous or improvisation. The more problems to be solved then the more the students learned so that their cognitive ability is increasing. Based on these descriptions, creativity is important for students, then the teachers have to facilitate them in the teaching and learning in the classroom.

3) The Students' Interest and Creativity Factor Influenced the Students' Learning Outcomes Together on the Economy Subject

The third hypothesis testing obtained tobtain value (8.370) $>$ ttable (1.701) which is accepted at a significance level of 5\%, then $\mathrm{Ho}$ is rejected and $\mathrm{Ha}$ is accepted, which means interest and creativity significantly affects the students' learning outcomes together on the Economy subject in X1 class in SMAN 1 Sambas. Thus, students who have high interest and creativity obtain high learning outcomes; otherwise, the students who have low interest and creativity obtain lower learning results. Students who have interest would welcome economy learning activities. The result is in line with the opinion of [21] who proposed: "interest as a person's tendency to accept or reject any activity". In addition to having an interest, having additional creativity in the learning process will certainly draw high learning outcomes. According to [22] creative learning encourages children to be sensitive and aware of the problems, deficiencies, gaps in knowledge, disharmony and so on, gathers information, shows elements that do not exist, search for answers, makes hypotheses, modifies, tests, enhances the communication system for the results. Therefore, it is proper for the teachers to provide greater opportunities for the development of students' interest and creativity in teaching and learning in order to improve learning outcomes.

\section{CONCLUSION AND RECOMMENDATION}

\section{A. Conclusion}

Based on the foregoing findings and discussions, it can be concluded that: (1) Interest significantly influenced students' achievement on the Economy subject at SMAN 1 Sambas. (2) Creativity significantly influenced students' achievement in economic subject at SMAN 1 Sambas. (3) Interest along with creativity gave a significant influence on students' achievement on the Economy subject at SMAN 1 Sambas.

\section{B. Recommendation}

Considering the above conclusions, there are certain recommendations triggered by the researcher:

1. The students are expected to be able to improve their interest in learning on the Economy subject which in turn increase their learning outcomes.

2. The students are demanded to increase their creativity in accomplishing tasks from their teacher.

3. The teacher should improve the quality of teaching as well as give the students much more opportunities to develop their interest and creativity in learning. With regard to this, the teacher needs to put extra effort in order to create the class atmosphere to be more motivating and provoking for students. Also, the teachers must set the situation that provides opportunities and stimulates the students especially to be interested on the Economy subject. This will involve choosing the right method, techniques, or strategies to boost students' enthusiasm for learning.

\section{REFERENCES}

[1] MeenuDev. (2016). Factors Affecting the Academic Achievement: A study of Elementary School Students of NCR Delhi, India. Journal of Education and Practice, 7 (4), pp. 70-74.

[2] Devadoss, S., \& Foltz, J. (1996). Evaluation of Factors in Fencing Students' Attendance and Performance. American Journal of Agricultural Economics, 78(3), 499 - 507.

[3] Aripin, R., Mahmood, Z., Rohaizad, R., Yeop, U., \& Anuar, M. (2003). Students' Learning Styles and Academic Performance. 22nd Annual SAS Malaysia Forum, 15th July 2008, Kuala Lumpur Convention Center, Kuala Lumpur, Malaysia.

[4] Romer, D. (1993). Do Students Go to Class? Should they? Journal of Economic Perspectives, 7(3), 167- 174.

[5] Reilley, Robert, R. \& Ernes, L. Lewis. (1993). Instructional Design. Theory and Models and Overview of their Current Studies. London: Lawrence Publisher. 
[6] Typhoon International Corp. (2004). The International Webster's Comprehensive Dictionary of the English Language: Encyclopedic Edition. USA: Trident Press International.

[7] Winkel, W.S. (1991). Psikologi Pendidikan dan Evaluasi Belajar. Jakarta: Gramedia.

[8] Kasijan Z. (1984). Psikologi Pendidikan Buku II. Surabaya: Bina Ilmu.

[9] Silvia, P. I. (2006). Exploring the Psychology of Interest. Retrieved January 9, 2017, from http://psycnet.apa.org/psycinfo/2006-03939-000

[10] Grainger, T. (2005). Teachers as Writers: Learning Together. English in Education. 39 (1), 75-87.

[11] Schiering, Majorie. S. (2016). Teaching Creative and Critical Thinking: An Interactive Workbook. London: Rowman \& Littlefield.

[12] George, J. M., \& Zhou, J. (2002). Understanding When Bad Moods Foster Creativity and Good Ones Don't: The Role of Context and Clarity of Feelings. Journal of Applied Psychology, 87, 687-697.

[13] Munandar, Utami. (1982). Pemanduan Anak Berbakat. Jakarta: Rajawali.

[14] Lefrancois Guy R. (1996). Psychology For Teaching. Bandung: Alumni.

[15] Skinner, B. F. (1958) Reinforcement Today. American Psychologist, 13, pp. 94-99.

[16] Hornby, A.S. (1987). Oxford Advanced Learner's Dictionary of Current English, Revised and Update. Oxford University Press.

[17] De Cecco, John P., and Crawford, William R. (1974). The Psychology of Learning and Instruction. Educational Psychology. New Jersey: Prentice-Hall, Inc., Englewood Cliffs.

[18] Cohen, L., Manion, L., \& Morrison, K. (2007). Research methods in education (6th ed.). New York: Taylor \& Francis e-Library.

[19] Department of Education. (2003). Pedoman Umum Pengembangan Bahan Ajar SMA. Jakarta: Direktorat Pendidikan Menengah Umum.

[20] Chandra J. (1994). Kreativitas. Jogjakarta: Kanisius

[21] Arikunto, S. (1990). Dasar-Dasar Evaluasi Pendidikan. Jakarta: Gramedia.

[22] Torrance, E.P. (1979). Future Careers For Creativity Student. Gilfred Child: 